\title{
PENGENDALIAN HAMA TIKUS DENGAN PENGASAPAN MODERN DITERAPKAN DI DUSUN SIDOMULYO
}

\author{
Elisa Sulistyorini ${ }^{*}$, Edwin Ramadhani Sampurna ${ }^{2}$, Hasan Basri ${ }^{3}$, Mochamad Firdaus Yulianto $^{4}$ \\ 1,2,3,4 Fakultas Teknik, Universitas 17 Agustus 1945 Surabaya, Jl. Semolowaru 45, Surabaya \\ Email: 1elisasulistyorini@untag-sby.ac.id; 2edwinramadhani@untag-sby.ac.id; 3albustomi833@gmail.com; \\ ${ }^{4}$ firdaus.yulianto.02@gmail.com \\ *Penulis korespondensi
}

\begin{abstract}
Abstrak: Desa Babakbawo memiliki luas 172,4 ha dan sebagian besar wilayahnya adalah dataran rendah yang tidak mengandung kapur sehingga pada umumnya masyarakat mengolah dan menggunakan tanah sebagai kolam, kebun, sawah dan lainnya. Sidomulyo adalah salah satu dusun di Babakbawo. Para petani di Sidomulyo menggunakan air dari Sungai Bengawan Solo untuk mengairi sawah. Hambatan besar pertanian di Sidomulyo adalah masalah hama tikus. Oleh karena itu, perlu ada solusi untuk membasmi tikus secara tepat dan efisien. Salah satu solusinya adalah metode merokok. Sebelum menggunakan perangkat ini, perangkat fogging yang mereka gunakan adalah perangkat fogging manual. Perangkat manual menggunakan tenaga tangan untuk menggerakkan kipas. Dalam penelitian ini metode fumigasi menggunakan fogging tikus modern dengan menggunakan motor listrik sebagai aktuator untuk mengaktifkan kipas di dalam perangkat. Perangkat fogging ini dibuat dengan tujuan agar petani lebih mudah memberantas tikus tanpa menyia-nyiakan tenaga dan waktu manusia. Perangkat ini diharapkan dapat meningkatkan kualitas dan kuantitas panen sehingga meningkatkan tingkat ekonomis di sidomulyo.
\end{abstract}

Kata kunci: Alat pengasapan, hama tikus, pertanian.

\begin{abstract}
Babakbawo village has an area of 172.4 ha and most of its area is lowland which does not contain lime so that in general the community cultivates and uses the land as ponds, gardens, rice fields and others. Sidomulyo is one of sub-village in Babakbawo. These farmers in Sidomulyo use water from the Bengawan Solo River to irrigate rice fields. The huge obstacle of agriculture in Sidomulyo is rat pest problem. Therefore, it is necessary to have a solution to eradicate rats appropriately and efficiently. One solution is the smoking method. Before use this device, fogging device that they used were manual fogging device. The manual device used hand power to actuate the fan. In this research method of fumigation using modern rat fogging by using a electric motor as an actuator to active the fan inside the device. This fogging device is made with the aim of making it easier for farmers to eradicate rats without wasting man power and time. The device is expected to improve the quality and quantity of the harvest so it increases the economical rate in sidomulyo.
\end{abstract}

Keywords: Fogging device; rat pest; agriculture.

\section{PENDAHULUAN}

Desa Babakbawo ini mempunyai luas 172.4 ha dan sebagian besar daerahnya merupakan dataran rendah yang tidak mengandung kapur sehingga pada umumnya masyarakat mengolah dan mempergunakan tanah tersebut sebagai tambak, kebun, sawah dan lain lain. Para petani ini juga biasanya memanfaatkan aliran sungai bengawan solo untuk pengairan sawah mereka. Berdasarkan jumlah penduduk di tahun 2015 Desa Babakbawo mempunyai jumlah penduduk 3136 ribu jiwa diantara- nya jumlah penduduk laki-laki sebanyak 1576 dan jumlah penduduk perempuan sebanyak 1560 jiwa, sedangkan 740 jumlah kartu keluarga.

Tikus merupakan hewan yang dapat bertahan hidup di semua tempat dan dapat beradaptasi dengan mudah terhadap lingkungan yang berubahubah. Selain berbahaya bagi manusia yang dapat menularkan penyakit berupa virus, tikus juga berbahaya untuk pertanian. Hama tikus pada lahan pertanian memang menjadi masalah serius dan harus segera diatasi untuk tetap menjaga kestabilan kualitas dan kuantitas dari panen. Jika masalah 
ini tidak teratasi dengan baik maka para petani akan mengalami kerugian yang sangat besar bahkan bisa menyebabkan petani gagal panen. Hal ini menyebabkan banyak petani di Dusun Sidomulyo beralih profesi dan merantau. Ada juga petani yang mengubah lahan pertaniannya menjadi tambak dan kandang untuk ternak ayam.

Perkembangan populasi tikus di lahan pertanian yang begitu pesat sangat sulit untuk dikendalikan. Beberapa faktor yang mempengaruhi sulitnya pengendalian hama tikus adalah hama tikus sawah relatif sulit dikendalikan karena memiliki sifat biologi dan ekologi yang berbeda dibanding hama padi lainnya, monitoring yang lemah mengakibatkan terjadinya ledakan populasi hama tikus sehingga menimbulkan kerusakan parah, tidak dilakukan antisipasi yang serius sehingga pengendalian lebih sulit dilakukan, pengendalian hama tikus pada umumnya dilakukan setelah terjadi serangan, tidak dilakukan pengendalian secara intensif, peralatan dan sarana pengendalian hama tikus yang terbatas, tidak ada kekompakan antara petani dalam mengendalikan hama tikus, dan tidak dilakukan pengendalian berkelanjutan sehingga populasi hama tikus terus meningkat [1].

Pengendalian hama tikus ini dibagi menjadi dua yaitu pengendalian secara fisik dan pengendalian secara mekanik [2]. Metode pengendalian hama tikus secara mekanis meliputi pengasapan, pembuatan rumah burung hantu, umpan beracun, dan pemasangan alat penyengat lisrik. Pengendalian hama tikus dengan cara mekanik adalah dengan diambil langsung atau penggeropyokan. Pengendalian hama tikus dengan membuat rumah burung hantu sangat efektif dan efisien. Biasanya menggunakan burung hantu jenis Tyto alba. Seekor burung hantu Tyto alba mampu memangsa $3-5$ ekor tikus per malam dengan radius terbang $12 \mathrm{~km}$ [3]. Kelemahan dari metode ini adalah masih sedikit petani yang mempunyai pengetahuan dalam membudidayakan burung hantu. Pengendalian hama tikus dengan menggunakan umpan racun sanga efektif tetapi sangat tidak dianjurkan. Penggunan umpan racun dalam pengendalian hama tikus dapat membahayakan anak-anak dan ekosistem disekitarnya, serta dapat menimbulkan bau tidak sedap apabila bangkai tikus tidak segera ditemukan. Pengendalian hama tikus dengan mengunakan sengatan listik juga sangat berbahaya. Selain dapat membunuh predator alami tikus juga dapat membunuh petani. Pengendendalian hama tikus dengan menggunakan pengasapan jauh lebih aman dari pada pengendalian hama tikus secara fisik lainnya. Pengendalian tikus secara pengasapan ini biasanya dikolaborasikan dengan metode pengendalian mekanik dengan pengoyokan. Alat pengasapan tikus yang digunakan dalam pertanian biasanya masih berupa alat yang manual dalam memutar kipas. Kipas yang digerakkan seara manual ini terkadang terkendala pada saat memutar dengan menggunkan tangan dan memerlukan tenaga yang besar untuk memutarnya.

Maka dari itu muncul ide untuk melakukan terobosan terbaru yang lebih aman dan efektif untuk membasmi hama tikus tersebut. Alat yang akan dibuat berupa alat pengasapan tikus modern. Alat ini dikatakan modern karena menggunakan motor listrik dalam menggerakan kipas. Fungsi utama dari alat ini adalah menghasilkan asap yang telah di campur dengan bahan kimia yaitu berupa pembakaran belerang, lalu asap yang di hasilkan ini di tujukan ke lubang atau sarang tikus yang terdapat di area sawah. Dengan adanya alat ini kualitas dan kuantitas panen lebih meningkat, sehingga meningkat pula perekonomian penduduk di Dusun Sidomulyo.

Alat pembasmi tikus dengan pengasap tikus sawah yang sangat efektif dalam mengusir tikus. Pengasap tikus ini dicari banyak petani karena sangat ampuh membasmi tikus sawah. Mesin dirancang dengan pengapian ignition coil tanpa busi sehingga efisien dan lebih baik. Material terbuat dari alumunium anti korosi dan Mesin Pengasapan dengan Teknologi yang diaplikasikan dengan belerang atau jerami yang dibakar, mudah dihidupkan karena menggunakan sistem kendali otomatis degan memanfaatkan teknologi motor DC sebagai pemutar tuas alat pengasap tikus dan power listrik yang digunakan adalah battery 12 volt sebagai sumber energi untuk motor DC dan untuk ignition coil sebagai pengapian-nya.

\section{METODE PELAKSANAAN}

Pengabdian masyarakat ini dilakukan di Dusun Sidomulyo. Objek dari pengabdian masyarakat ini adalah petani Dusun Sidomulyo. Pengabdian masyarakat ini dilakukan di area pertanian Dusun Sidomulyo, Desa Babakbawo, Kecamatan Dukun, Kabupaten Gresik. Kegiatan PKM ini dilakukan pada mitra dalam meningkatkan hasil produksi pertanian baik dari segi kualitas maupun kuantitas dengan memberikan penyuluhan, pendampingan, dan pengembangan teknologi tepat guna untuk pengendalian hama tikus yang ada di area pertanian mitra. Selain mendapatkan alat teknologi tepat guna berupa pengasapan modern untuk membasmi tikus. mitra diberikan penyuluhan dan pendampingan tentang cara penggunaan alat teknologi tepat guna tersebut. Alat teknologi tepat guna yang diberikan ke kelompok tani berupa 3 set alat pengasapan tikus modern yang diterima oleh kepala Dusun Sidomulyo.

Sebagai satu alat pengendali hama tikus adalah dengan metode pengendalian scara fisik, yaitu dengan pengasapan atau sering disebut juga 
pengemposan. Metode ini biasanya diakukan dengan pembakaran serbuk belerang sehingga menghasilkan racun berupa asap yang didistribusikan ke lubang aktif sarang tikus yang ada di lahan pertanian dan sekitarnya. Alat pegasapan yang banyak dipakai petani masih berupa alat pengasapan secara manual. Penggerak kipas untuk mendistribusikan asap masih menggunakan tangan.

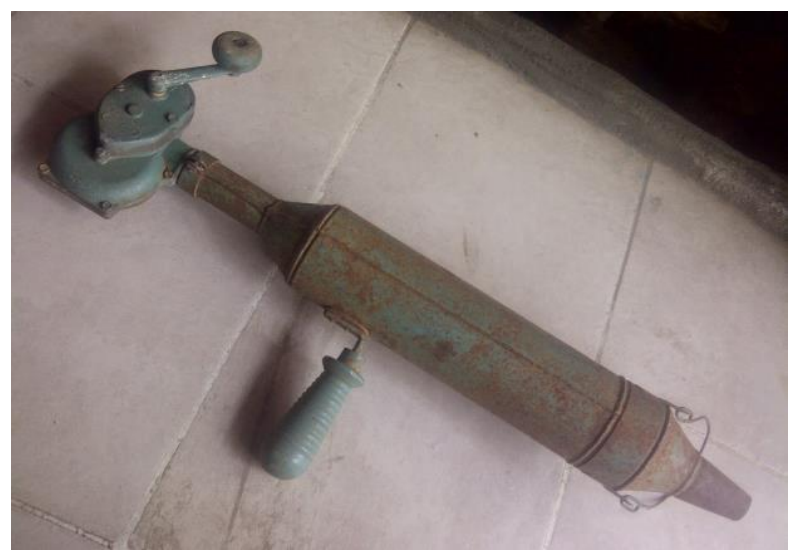

Gambar 1. Alat Pengasap Tikus Secara Manual

Sumber: http://koleksikunoanggoro.blogspot.com/2015/05/ alat-pengasap-tikus.html [4]

Alat teknologi tepat guna yang dibuat untuk kegiatan pengabdian masyarakat di Dusun Sidomulyo ini berbedadengan produk pengasapan tikus yang ada di pasaran. Alat teknologi tepat guna yang dibuat kali ini adalah alat pengasapan yang menggunakan motor elektrik untuk menggerakkan kipas yang berfungsi mendistribusikan asap ke sarang tikus. Hal ini memudahkan petani untuk menggunakan alat pengasapan modern ini sehingga menghemat waktu dan tenaga. Alat pengasapan modern ini sangat efektif dan efisien dalam Mengendalikan hama tikus. Adapun desain alat pengasap modern ini adalah sebagai berikut.

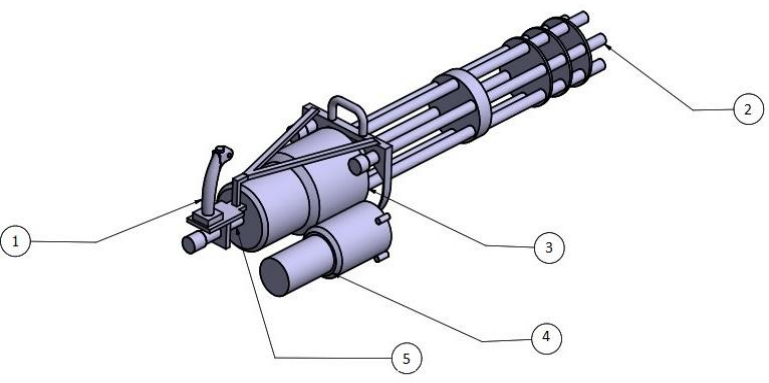

Gambar 2. Desain Alat Pengasapan Modern

Komponen-komponen dari alat pengasapan modern ini adalah:

1. Tuas Pemegang

2. Cerobong Pipa Asap

3. Tabung Pembakaran

4. Motor DC

5. Pemantik Api
Tuas pemegang berfungsi untuk memudahkan petani untuk memegang alat teknologi tepat guna pengasapan modern sehingga meminimalisir kecelakaan tangan pengguna pada saat pembakaran berlangsung. Tuas pemegang ini juga terbuat dari alumunium yang $d$ balut dengan bahan karet untuk menghambat panas yang terpancarkan dari alat pengasapan modern mengalir ke tuas pemegang. Cerobong pipa asap berfungsi untuk mendistribusikan asap untuk diarahkan ditarget sasaran berupa lubang tikus yang aktif. Tanpa cerobong pipa, asap akan terdistribusi menyebar sehingga tidak optimal dalam pengendalian hama tikus yang ada di lahan pertanian para petani.

Tabung pembakaran berfungsi sebagai wadah pembakaran untuk menghasilkan asap beracun yang dapat membasmi hama tikus. Motor DC magnet permanen berfungsi untuk memutar tuas baling-baling kipas yang sudah terinstal di dalam tabung pembakaran. Tipe motor yang digunakan untuk memutar kipas adalah motor DC $12 \mathrm{~V}$ type DA061GA301 rpm 142, dan baterai yang digunakan sebagai sumber power pada motor DC adalah Panasonic NCR18650B Li-ion Battery 3400mAh 3.6V 30A. Pemantik api berfungsi untuk menghasilkan percikan api yang digunakan untuk pembakaran di ruang tabung pembakaran. Tipe pemantik yang digunakan adalah Elektrik Heating Coil Rechargeable - JD-YQ016 yang dihasilkan dari baterai. Adanya komponen motor DC dan pemantik inilah yang menjadi keunggulan pengasapan modern dibandingkan dengan pengasapan modern.

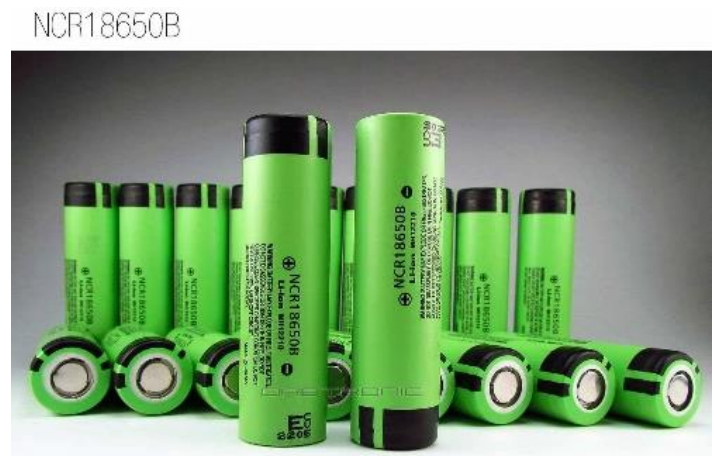

Gambar 3. Panasonic NCR18650B Li-ion Battery Sumber: https://www.orbtronic.com/batteries-chargers/panasonic-3400mah-18650-li-ion-battery-cell-ncr18650b [5]

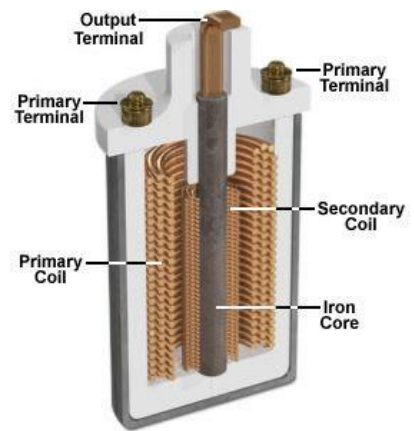

Gambar 4. Materi Ignition Coil

Sumber: https://www.autoexpose.org/2017/02/cara-kerja-ignition-coil.html [6] 
Adapun spesifikasi dari alat pengasap tikus modern ini adalah sebagai berikut;

1. Dimensi pada alat pengasapan tikus yaitu 1100 x 360 x $380 \mathrm{~mm}$

2. Berat yang dimiliki bekisar $2.5 \mathrm{~kg}$.

3. Material yang digunakan untuk membuat mesin pengasapan moderen ini adalah alumunium

Cara Menyalakan mesin pengasap tikus hanya dihubungkan ke kabel power ke listrik dimana sumber energi menggunakan Baterai DC12 volt dengan kapasitas daya 3400 watt, sedangkan motor yang digunakan adalah Motor DC Magnet Permanent dimana sebuah piranti elektronik yang mengubah energi listrik menjadi energi mekanik berupa gerak rotasi. Pengisian baterai ini membutuhkan waktu kurang lebih dua jam. Pengapian pada alat ini menggunakan ignition coil yang merupakan alat yang vital untuk pengapian belerang/jerami sehingga menghasilkan asap yang lebih praktis dan modern.

Cara kerja alat pembasmi tikus dengan pengasap tikus sawah yaitu siapkan belerang, arang, dan jerami/serbuk gergajiatau bisa deganti dengan jeramiyang kemudian campurkan menjadi satu, masukkan ke dalam tabung pembakaran. Untuk memudahkan pembakaran ditambahkan arang dan jerami sebagai campuran belerang. Perbandingan antara serbuk belerang dan arang adalah 1:1. Jerami yang didicampurkan ke tabung pembakaran disesuaikan dengan kebutuhan di dalam tabung pembakaran. Setelah dimasukkan ke dalam tabung pembakaran, kemudian belerang dibakar. Setelah itu cerobong pipa diarahkan ke dalam lubang tikus yang aktif. Lalu nyalakan motor DC dimana sebagai pemutar tuas alat tersebut sehingga asap bisa masuk ke dalam lubang. Perhatikan area sekitar sawah bila ketika ada asap keluar, maka itu adalah jalan tembus lubang tikus tersebut dan biasanya tikus akan keluar dari lubang yang keluar asapnya/ mati didalamnya. Jika asap yang dihasilkan menipis, matikan alat dan proses pembasmian hama tikus selesai. Jika masih ada sarang atau lubang tikus aktif yang akan diasapkan, maka isi kembali tabung pembakaran dengan serbuk belerang, arang, dan jerami. Setelah itu tutup kembali tabung dan aktifkan saklar motor dan arahkan ujung mulut alat pengasapan tikus modern ke dalam lubang aktif tikus hingga asap tidak ada kemudian matikan saklar. Setelah lubang aktif tikus diiasapi, tutuplah lubang tikus dengan menggunakan lumpur basah. Menutup lubang tikus mempunyai keuntungan sebagai berikut:

a. Tikus dan anak-anaknya akan mati karena tidak bisa keluar dari lubang

b. Lubang tersebut tidak bisa lagi digunakan untuk sarang tikus yang lain

c. Infrastrktur pertanian tidak rusak

d. Bau bangkai tikus-tikus yang mati di lubang itu tidak akan tercium keluar
Sebelum melakukan pengasapan, perlu diketahui dahulu lubang-lubang tikus yang aktif. Ciriciri lubang tikus yang aktif adalah lubang berukura lima hingga delapan sentimeter. Lubang itu panjang dan bercabang yang terdapat rruangan yang membesar untuk tikus betina melahirkan dan menempatkan anak-anaknya.

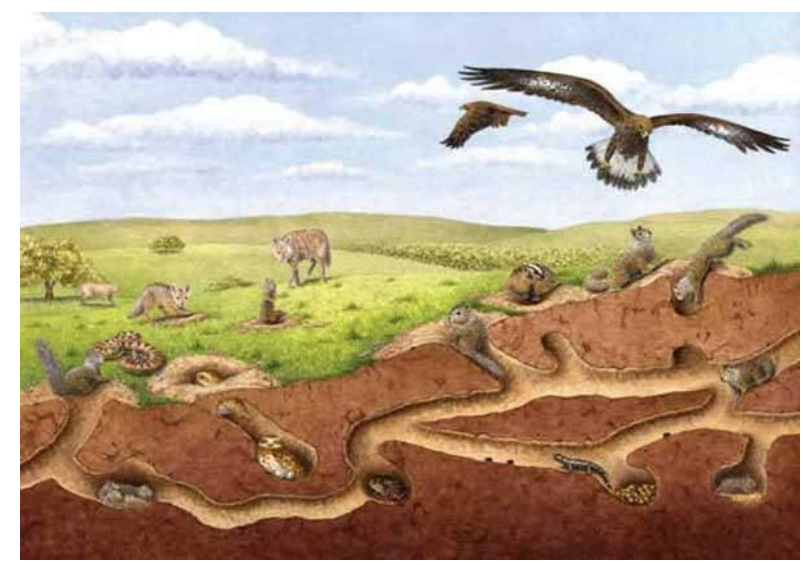

Gambar 5. Lubang Tikus yang Aktif

Sumber: https://takegreen.wordpress.com/2011/12/16/tikustanah-yang-tidak-tahu-waktu/star-nosed-mole/_[7]

Untuk perawatan alat pengasapan moderen ini sangat mudah, setelah dipakai bersihkan alat sebersih mungkin dan disimpan ditempat yang aman dari bahaya zat kimia. Untuk pengisian baterai diperlukan pengisihan penuh selama 2, setelah baterai terisi penuh pastikan untuk mencabut kabel power dari sumber arus setelah itu pastikan kondisi alat dalam keadaan mati total.

\section{HASIL DAN PEMBAHASAN}

Hama tikus merupakan momok terbesar di bidang pertanian di wilayah Kecamatan Dukun umumnya dan Dusun Sidomulyo khususnya. Hama tikus ini menyebabkan para petani gaga anen berkali-kali sehingga merugi. Kerugian dari gagal panen berkli-kali ini sangatlah besar. Banyak warga Dusun Sidomulyo yang beralih profesi untuk bertahan hidup. Banyak juga warga yang mengubah lahan pertanian mereka menjadi tambak dan kandang ayam. Ada juga warga yang memilih merantau ke surabaya dan sekitarnya untuk berjualan dan bekerja di warung kopi. Jika ini tetap berlangsung maka pertanian di Dusun Sidomuyo semakin menurun dan akan menambah angka pegangguran.

Kegiatan pengabdian masyarakat pengendalian hama tikus dengan menggunakan pengasapan modern ini sangat membantu para petani khususnya dan warga mayarakat umumnya yang berada di Dusun Sidomulyo, Desa Babakbawo, Kecamatan Dukun, Kabupaten Gresik, Jawa Timur. Para 
petani dapat memahami dan mengimplementasikan penyuluhan yang telah diberikan. Para petani juga sudah dapat memahami dan mengaplikasikan ketiga alat teknologi tepat guna yang telah diberikan pada lahan pertanian.

Setelah menggunakan alat pengasapan modern dalam pengendalian hama tikus di Dusun Sidomulyo ini sangat efektif dan efisien. Selain mudah digunakan para petani, alat teknologi tepat guna ini juga tidak mempunyai efek samping yang membahayakan ekositem maupun warga yang berada di Dusun sidomulyo. Bahan-bahan pendukung yang digunakan untuk mengoperasikan alat pengasapan tikus modern ini sangat mudah diperoleh dan harganya cukup terjangkau sehingga mengurangi biaya produksi dari para petani. Penggunaan alat teknologi tepat guna pengasapan modern sangatlah mudah dan tidak membutuhkan tenaga fisik yang besar dalam pengopersiannya sehingga para petani dapat melakukannya dengan cepat dan menghemat waktu dan tenaga. Selain itu, perawatan dan pengisian ulang daya dari alat teknologi tepat guna pengasapan modern ini sangatlah mudah.

Populasi hama tikus di Dusun Sidomuyo sudah mulai berkurang. Hal ini terbukti dengan jumlah bangkai tikus yang ditemukan pada saat setelah para petani melakukan pengasapan di lahan petanian rata-rata semakin meningkat. Biasannya kegiatan pengendalian hama tikus pada lahan pertanian dilakukan berhari-hari untuk mendapatkan beberapa ekor tikus di lahan pertanian. Data jumlah bangkai tikus yang ditemukan dari beberapa kegiatan pengendalian hama tikus dengan menggunakan alat teknologi tepat guna pengasapan modern periode bulan Juli pada lubang 1 tikus yang aktif adalah sebagai berikut.

Tabel 1. Data Jumlah Bangkai Tikus pada Lubang 1 Aktif Periode Juli

\begin{tabular}{ccc}
\hline No. & Kegiatan ke- & Jumlah tikus \\
\hline 1. & 1 & 3 \\
2. & 2 & 4 \\
3. & 3 & 5 \\
4. & 4 & 6 \\
5. & 5 & 5 \\
6. & 6 & 7 \\
7. & 7 & 8 \\
\hline
\end{tabular}

Pengendalian hama tikus yang efektif dan efisien ini membuat para petani di Dusun Sidomulyo bersemangat dan optimis hasil panen dimasa yang akan datang jauh meningkat dibadingkan dengan yang sebelumnya.
Hasil panen berikutnya dapat lebih meningkat dari segi kuantitas maupun kualitas daripada hasil panen periode sebelumnya. Dengan meningkatnya hasil panen periode berikutnya diharapkan dapat mengembalikan fungsi awal lahan-ahan pertanian yang sudah menjadi tambak dan kandang ayam. Dengan begitu, perekonoian warga Dusun Sidomulyo akan meningkat.

\section{SIMPULAN DAN REKOMENDASI}

Alat teknologi tepat guna pengasapan modern ini mampu mengendalikan hama tikus yang ada di lahan pertanian Dusun Sidomuyo, Desa Babakbawo, Kecamatan Dukun, Kabupaten Gresik, Jawa Timur. Alat ini dapat mengurangi populasi hama tikus yang ada di lahan pertanian Dusun Sidomuyo. Dengan berkurangna populasi tikus dapat meningkatkan kualitas dan kuantitas panen periode mendatang. Dengan meningkatnya kualitas dan kuantitas panen akan meningkat perekonomin pula warga Dusun Sidomulyo. Selain itu perawatan alat pengasapan modern sangatlah mudah. Bahan baku yang digunakan untuk proses pengasapan tikus mudah dicari dan harga terjangkau.

\section{DAFTAR PUSTAKA}

Azzamy, "Mitalom.com," 04 November 2016. [Online]. Available: https://mitalom.com/metode pengendalian-hama-tikus-sawah/.

“agrotekuin.com," 2709 2012. [Online]. Available: http://agrotekuin.com/images/materi/download. php?fil=PERT\%20III\%20PENGENDALIAN\% 20FISIK\%20DAN\%20MEKANIK.pdf\&ID=64.

N.M.S. Sukmawati, N.S. dan N.K., "Pengembangan Burung Hantu (Tyto Alba) Sebagai Pengendali Hama Tikus Di Desa Babahan Dan Senganan, Penebel, Tabanan, Bali," Buletin Udayana Mengabdi, vol. 16 No. 1, p. 7, Januari 2017.

"Koleksi Antik Anggoro Solo," 2005 2015. [Online]. Available: http://koleksikunoanggoro.blogspot. com/2015/05/alat-pengasap-tikus.html.

"orbtronics.com," 2009. [Online]. Available: https://www.orbtronic.com/batteries-chargers/ panasonic-3400mah-18650-li-ion-battery-cellncr18650b.

“autoexpose.org," 2018. [Online]. Available: https://www.autoexpose.org/2017/02/cara-kerjaignition-coil.html.

"The Blue Earth," [Online]. Available: https://takegreen.wordpress.com/2011/12/16/tik us-tanah-yang-tidak-tahu-waktu/star-nosedmole/. 